\title{
Public occasions, Indigenous selves: three Ngarrindjeri autobiographies
}

\author{
Tim Rowse
}

Through Indigenous autobiography Indigenous Australians have found voice as historians. ${ }^{1}$ To write the history of one's own life has become the dominant genre of Indigenous written historical practice. ${ }^{2}$ Note that I am using the word 'write' loosely to refer to what we readers suppose the Indigenous author to have done. In this paper, I do not care whether the 'author' is the sole producer of the text, and I do not differentiate between written/edited and spoken/transcribed/edited modes of production. Rather, my reading strategy is to assume that these three books by Doris Kartinyeri, Veronica Brodie and Dulcie Wilson are authentically autobiographical. Notwithstanding our knowledge that the mode of literary production involves persons and institutions in addition to the author, we can read autobiography as a person's knowing narration of his or her own life.

1. The corpus of writings 'Australian Indigenous autobiography' is not well defined. An online annotated bibliography of Indigenous autobiography would be a good project, along the lines of David Brumble III's American Indian autobiography (1988). There will always be problems of classification. Is The town grew up dancing (Green and Rubuntja 2002) a biography or an autobiography? Should we include Gordon Matthews' An Australian son (1996) if that book addresses the (in)significance of the author not being of Aboriginal descent? Vaulting over problems of genre definition, I estimate that there are at least 100 items to include in such a bibliography, from essays to books, and that about $65 \%$ of the authors are female. The best known is probably Sally Morgan's My Place (1987). The price of Morgan's success is that her book has a US edition with a picture of Uluru on its cover. There are signs of the emergence of a critical canon of Indigenous autobiographies; a tendency whose prematurity I discuss in 'Indigenous autobiography in Australia and the United States' (Rowse 2004).

2. For some US writings relevant to Indigenous autobiography, see HD Wang Sending my heart back across the years (1992); J Watson and S Smith (1992); D Murray Forked tongues: speech, writing and representation in North American Indian texts (1991); LW O'Brien Plains Indian autobiographies (1973). The work of Arnold Krupat stands out as a continuing thoughtful engagement with North American Indian autobiography: For those who come after (1985); The voice in the margin: Native American literature and the canon (1989); 'Native American autobiography and the synecdochic self' (1992); Native American autobiography: an anthology (1994). On Australian Indigenous autobiography there is a growing literature that I will not try to survey here. It includes: D McCooey Artful histories (1996); Anne Brewster Aboriginal women's autobiography (1996) and 'Aboriginal life writing and globalisation: Doris Pilkington's Follow the rabbit-prooffence (2002); R Dalziell Shameful autobiographies (1999); J Hooton Stories of herself when young (1990); G Whitlock The intimate empire: reading women's autobiography (2000). 
Autobiography rests on the idea that humanity is made up of unique individuals whose individuality (a) is of intrinsic interest and value, and (b) can be understood as having its own history. Autobiography, like some other literary genres such as the novel, serves a sensibility that acknowledges and values the intentionality and interiority of persons. Autobiography, again like some other genres of writing such as biography, assumes that the object of its representation has a history, that is, that there can be a story of the contingencies of an individual's interactions with peoples and things beyond him/herself. Autobiography is different from the novel in that the question of factual truthfulness is relevant to an autobiography. The particular claim to be truthful that autobiography makes is that the autobiographer has privileged access to the interiority that is essential to his/her uniqueness. 'No one can know better than I what I have thought, what I have wished; I alone have the privilege of discovering myself from the other side of the mirror - nor can I be cut off by the wall of privacy. ${ }^{3}$ This unique degree of access to the remembered interior of the narrated self differentiates autobiography from biography. Even biographies based on intimate diaries cannot match the autobiographer's access to his or her interiority. ${ }^{4}$ Autobiographical truth is in this sense 'interested', not disinterested; our respect for autobiography rests partly on an implicit conviction that "no one can better do justice to himself than the interested party ${ }^{\prime}$.

Autobiography tends to unify the narrated life, to emphasise its underlying continuities as it moves towards the ' $\mathrm{I}$ ' that the autobiographer, at the time of writing, understands him or herself to be. Weintraub prefers to call this movement to the present 'development'; he considers the word 'unfolding' to be better suited to nonhuman life forms. 'Development' conveys a necessary element of human intentionality, of reflective interaction with the world's contingencies that is missing from 'unfolding'. We can read autobiographies as cohering around a point of view on the many contingencies of that development, a point of view that sorts events in terms of their relevance to the plotted trajectory of the life story. The autobiography is a 'means to self knowledge thanks to the fact that it recomposes and interprets a life in its totality'. ${ }^{7}$ Autobiographies thus evince a sense of destiny: the life I tell produced the ' $\mathrm{I}$ ' that is now narrating. As Gusdorf says, 'the original sin of autobiography is first one of logical coherence and rationalisation'. 8

If self-conceptions are so important, where do autobiographers get them? Weintraub suggests that the possible sources of self-conceptions have shifted since the

3. Gusdorf 1980: 35 .

4. I do not assume that every autobiography exploits the genre's capacity for intimate selfrevelation. Indeed, some autobiographies are intriguing because they lack what is usually understood to be a language for signifying the intimate self. I found this to be a feature of Ruby Langford's Don't take your love to town (Rowse 1993a). This raises the interesting question of how readers are trained to regard certain aspects of 'self' as intimate or deep and others as external and public. An effective practice of reading will include some reflection on these distinctions, which are easily taken for granted.

5. Gusdorf 1980: 36 .

6. Weintraub 1975: 830.

7. Gusdorf 1980: 40.

8. Gusdorf 1980: 41. 
Renaissance as 'individuality' has come to be more valued. Cultures hold out models that express values and convictions, but such models, he argues, have been rivalled by the growing value attached to the idea that each self may demand to be understood in its own unique terms. ${ }^{9}$ Invited to make sense of themselves in terms of our culture's models, autobiographers can see themselves as approximations to these models or as deviations from them.

Television journalist Stan Grant writes of himself as an Aboriginal man. He introduces The tears of strangers by announcing that he is uneasy with the received ideas of an Aboriginal life. White Australia, he writes,

is recreating Aboriginal society as it imagines it should be; it's a blackness seen through white eyes and offers blacks something to believe in, or even cash in on. But it offers no freedom, simply subservience. We have moved beyond the fact of race and arrived at race as a concept. We are chained to the predictability of Aboriginal identity by a laziness that fails to grapple with our inconsistencies and fraudulence; we remain perplexed by our very existence. ${ }^{10}$

Few Indigenous authors are as self-laceratingly at odds as Stan Grant with what they declare to be the available models of Aboriginality.

Sally Morgan, in contrast, builds her story of self-discovery upon a notion of Aboriginal identity which she does not question: identity based on acknowledged descent. For Morgan, the question: 'Who am I?' can be answered with certainty, as long as she challenges the lies that have obscured her descent. Presenting herself as a truth-seeker, she interrogates the heritage of shame and deceit that obscured the truth of her descent and identity. ${ }^{11} \mathrm{My}$ place starts and finishes with an established notion of Aboriginality as descent. There is no such secure model for Stan Grant. He cannot accept descent as an adequate criterion of Aboriginality because he is so conscious of the variety in the life experiences of people of Aboriginal descent. As an Aboriginal 'success' he feels guiltily estranged from Aborigines whose lives are blighted. His book cannot formulate a notion of Aboriginal identity that would accommodate the huge differences among people of Aboriginal descent. He mercilessly exposes his own and others' inclination to truncate this Aboriginal heterogeneity. 'We have a perverse longing, a lingering attachment to the injustice and oppression that we imagine nourish our identity. Shamelessly, we compete for victim status and turn pain and loss into virtues. ${ }^{\prime 2}$ To be middle class, he tells us, is to embody an Aboriginality that cannot speak its name. The question that Stan Grant poses to himself about his Aboriginality gets no secure answer in The tears of strangers.

The Morgan/Grant contrast illustrates the different ways that Indigenous autobiographers may handle received notions of Aboriginality. Neither can ignore that certain notions of Aboriginality are established in Australia's public culture. For both authors, Aboriginality as descent is a point of reference. 'Descent' works for Morgan; she uncovers the truth of her descent. Grant's descent has never been hidden from him,

\footnotetext{
9. Weintraub 1975: 837 .

10. Grant 2002: 5.

11. Morgan 1987.

12. Grant 2002: 5.
} 
but he finds descent insufficient as a basis for his identity because of the weight he attaches to the class and generational differences among those of Indigenous descent.

There are other public notions of 'Aboriginality' with which an individual may align their individuality. 'Suffering' works for Doris Kartinyeri (as I will show below) as shared Aboriginal heritage.

All autobiographers whose self-understanding includes being 'Aboriginal' must negotiate some relationship with some publicly available notion of 'Aboriginality'. What is individual (my life) will be explained in reference to what is understood to be typical of Aboriginal Australians.

Aboriginal autobiography is a recent phenomenon in Australian history; it occurs within what Jeremy Beckett calls 'welfare colonialism', in which authorities solicit, rather than discourage, 'Aboriginalities'. ${ }^{13}$ Australia's public culture now abounds in notions of 'the Aboriginal' - many of them affirmative, many still devaluing. Do representations of Aboriginality have a disciplinary effect on those who understand themselves to be, and who present themselves as, 'Aborigines'? Elizabeth Povinelli evokes the multiplicity and the incommensurability of the regimes of recognition of Aboriginality. If Aborigines are under the influence of these regimes, then they are multiply influenced and have some latitude in their invocations of identities. 'We have here ... a set of incommensurate, though often mutually referring, state regimes sitting alongside a set of incommensurate, though often mutually referring, local social regimes. Both sets are constantly invaginating each other as people make use of them to advance their particular social aspirations. ${ }^{14}$ As Gill Cowlishaw has recently argued, we should not suppose that there are points of correspondence between professional and vernacular understandings of Aborigines' collective history. ${ }^{15}$ Both Povinelli and Cowlishaw, as I understand them, are pointing to the space for an author to puzzle over the relationship between 'me' and the public Aboriginalities of which ' $\mathrm{I}$ ' may or may not be an instance.

One of the tasks of Aboriginal autobiography is to invite reflection on the relationship between widely available public representations of 'the Aboriginal experience' and that which the autobiographer understands to be unique to him/herself. Indigenous Australians who are addressed as the 'Aboriginal' objects of governmental concern have the task or the opportunity to respond to this address. We can understand their behaviour and their expression, particularly their autobiographies, as a response - compliant or resistant - to what the established public accounts of Aboriginality say it is. There may be many sources and occasions for these representations of Aboriginality, and many ways to feel comfortable or uncomfortable in one's relationship to them. $^{16}$

\section{Three Ngarrindjeri selves}

The Ngarrindjeri people of south-eastern South Australia were exposed to an extraordinary burst of public attention to their heritage in the years 1994 to 2001, in what has

13. For a discussion of Beckett's and similar arguments see Rowse 1993b: 53-9.

14. Povinelli 2006: 157.

15. Cowlishaw 2005. 
become known as the Hindmarsh Island Bridge Affair. In three autobiographies - Dulcie Wilson's The cost of crossing bridges, Doris Kartinyeri's Kicking the tin and Veronica Brodie's My side of the bridge we can see different ways that Ngarrindjeri women have responded to the contested representations of Ngarrindjeri by narrating their individual Ngarrindjeri-ness. ${ }^{17}$

In July 1994, the federal Minister for Aboriginal Affairs Robert Tickner invoked Aboriginal heritage protection legislation to place a 25-year ban on the construction of a bridge that would connect Hindmarsh Island to the mainland. He relied on the testimony of certain Ngarrindjeri people, backed by reports from 'experts', that the bridge would damage areas of water and land that were sacred in the secret traditions of Ngarrindjeri women. The ban was controversial. One of the most serious objections came from some Ngarrindjeri women who denied that there was a body of customary secret knowledge endowing the bridge area with sacred significance. These objectors did not necessarily want the bridge; they were angry at what they saw as a misrepresentation of Ngarrindjeri heritage by those who had asked for the ban on the bridge. From June to December 1995, the South Australian government's Royal Commission investigated the 'dissident' women's allegation that the 'secret women's business' was a fabrication. Most of those who proposed the bridge ban and believed in the secret women's business refused to appear before the Royal Commission. The Royal Commissioner, Iris Stevens, found the secret women's business to have been fabricated. An investigation by Justice Jane Mathews in 1996 advised the Minister for Aboriginal Affairs John Herron that the bridge site did have genuine customary significance for the women who had supported the bridge ban. In her report, which was not widely circulated, she wrote that because these women chose not to reveal to her the secrets of the site, she was unable to conclude that the building of the bridge would be a serious breach of Ngarrindjeri law.

The bridge was constructed.

Meanwhile, developers whose interests had been threatened by Tickner's ban sued him and several of the 'experts' on which he had relied. In his judgment on this case in 2001, Justice von Doussa critically reviewed the 1995 Stevens Royal Commission, discrediting its finding of 'fabrication'. Thus, over a seven-year period, two competing representations of the content of Ngarrindjeri law had been put before the public, and each of these representations had been both supported and contradicted by a Royal Commissioner and two judges. The case raised the question of who has the authority to speak for the Ngarrindjeri - a question whose answer cannot avoid some delving into the life history of key Ngarrindjeri persons. ${ }^{18}$

16. For example, ethnographic representations of Indigenous people may give an account of their culture that brings a sense of shame. Some Ngarrindjeri people did not feel comfortable with the ethnographic representation of Ngarrindjeri culture in Berndt and Berndt (1993) - a book published more than fifty years after the fieldwork on which it was based. It seems that some Ngarrindjeri were upset at the book's intimate sexual material and at its passages about Ngarrindjeri sorcery (Simon 2003: 115).

17. Wilson 1998; Kartinyeri 2000; Brodie 2002.

18. I strongly recommend Margaret Simon's The meeting of the waters (Simon 2003) as a narrative of the Hindmarsh Island affair. 


\section{Dulcie Wilson}

Dulcie Wilson was one of the leading critics of the claim that there was secret women's law threatened by the proposed bridge. She wrote The cost of crossing bridges in the wake of the Royal Commission that vindicated her dissidence, but before the von Doussa judgment reinstated the credibility of the women's law. Wilson's book is only partly an explicit commentary on the Hindmarsh Island dispute: the final third of its 187 pages, titled 'Today's bridges', is a passionate and triumphant account of her own part in it. Much of the book was conceived and executed before that controversy erupted. That is certainly true of the middle section, about one-fifth of the book, in which her husband Lindsay remembers his working life in the south-east of South Australia ('Lindsay's bridges'). Lindsay died in April 1994, before 'the Hindmarsh Island saga reared its ugly head'. ${ }^{19}$ The book offers no definite information as to whether Dulcie composed the first 90 pages ('Early bridges') before or after she began to speak her mind on Hindmarsh Island. 'Early bridges' is about growing up at Raukkan (Point McLeay Mission), marrying Lindsay, leaving Raukkan and working in the Salvation Army. The narrative of her pre-Hindmarsh life establishes Dulcie as a devoutly Christian Ngarrindjeri who is proud of her Aboriginal heritage.

Placed in front of these three long sections are two short pieces of writing that function as prologues. The first ('Prologue') recalls the moment of Lindsay's death, her grief and her decision to write: 'doing something positive, which is not only therapy for my loneliness, but will, I hope, bring enlightenment and understanding to those who read my story'.$^{20}$ In the second, 'My awakening', Dulcie commits herself to revealing that certain Aboriginal people were misrepresenting Aboriginal culture, history and aspirations. This announces the point of her book: to correct prevailing misrepresentations of Aboriginal culture, in particular the erroneous (to Dulcie) view that there is 'secret women's business' on Hindmarsh Island. The contemporary self projected by Dulcie - the book's controlling figure - is that of a virtuous truth-teller, a Ngarrindjeri Christian who courageously stands up to the Aboriginal and nonAboriginal 'proponents' of the secret and sacred law of Hindmarsh Island. How does the autobiographical narrative substantiate that self?

Dulcie Rigney was born on Raukkan in 1932; she grew up at a time when both law and social norms understood caste and colour to be determining and indicative of character. She tells us that her skin was relatively white (a photo confirms this). 'We were never really accepted into the Aboriginal community because we were tainted by our European inheritance, nor were we accepted by the white community because we came from an Aboriginal mission with the stigma of primitive man. We were people in limbo with nowhere to go. ${ }^{21}$ And the response of Raukkan's children to her colour caused her to be 'shy and introverted ... with no confidence in myself'. ${ }^{22}$ As an adult she learned from her uncle Bruce that she should not ask questions about her family's past; family trees, for these people of mixed descent, were contentious, and knowledge of the past had the potential to hurt and to 'disgrace ... the family name and honour' ${ }^{23}$ These

19. Wilson 1998: 139.

20. Wilson 1998: 4.

21. Wilson 1998: 15-16.

22. Wilson 1998: 15. 
cautionary words introduce a relatively impersonal account of her childhood in which the Raukkan community's hard work, cleanliness, piety and material austerity are prominent themes.

The community in which she grew up, from 1932 to 1957 , consisted of four or five hundred people, mostly living in one or two bedroom cottages built of sandstone or of timber and iron. Dulcie's mother was a domestic servant of the Mission school's head teacher, WT Lawrie; her father was a shearer, away for months at a time. When her mother died in 1944, 12-year-old Dulcie lived with her grandmother and her uncle Bruce (Dulcie does not differentiate paternal from maternal kin). She describes how people worked, and she names and briefly profiles men and women whose hard work she recalls with admiration. She remarks with approval that she was firmly disciplined as a child. Strictness in the household reinforced the government's tight regulation of the community: alcohol consumption and gambling were banned. The Salvation Army began to work in the community in the 1940s.

That the children of Raukkan's white staff were educated elsewhere began to make Dulcie aware of the importance of race. She writes that she has tried throughout her life to adhere to an ideal of multi-racial community, in which all people are treated the same, no matter what their colour or background. Her (and her husband's) personal triumph over other people's prejudices about Aborigines is a thread that runs through her stories.

Dulcie left school in 1947 (when she was 15) to be a domestic servant in the household of the Mission's dairy overseer. Later she mentions going grape-picking. She tells very little of her experience of employment over the ten years that elapsed between leaving school and leaving the Mission. Nor does she say why she and Lindsay Wilson (a Raukkan resident whom she had married in 1950) decided to leave Raukkan where she felt 'very safe and secure' - other than to insist that it was a chosen, not a coerced, move. ${ }^{24}$ Lindsay is more forthcoming.

We moved to Millicent when there was a push to move us out, to assimilate amongst the white people. I didn't mind moving away from the Mission, because ... the wages weren't flash at Point McLeay and work was hard to come by. Dulcie and I could not see at that particular time that things were going to improve. ${ }^{25}$

He recalls that they resisted the Department of Aboriginal Affairs' suggestions about where he, Dulcie and their three children might settle. They preferred Millicent because the Salvation Army was active there. Their move from Raukkan thus seems to have combined personal choice, labour market inducement and State government and Salvation Army encouragement to assimilate into the white community. Characteristically, Dulcie's first story about settling in Millicent illustrates how diligently she kept track of her rental payments.

Assimilation was an opportunity for Dulcie, and she grasped it eagerly. She is proud that she has never allowed the narrated incidents of white prejudice to undermine her belief in her own place in the Australian community. She sees no limits to the

23. Wilson 1998: 19.

24. Wilson 1998: 58.

25. Wilson 1998: 104. 
Aboriginal potential to 'progress' and to 'raise their standard of living', though she acknowledges that 'in some areas' 'the humpy and handout mentality' continues. ${ }^{26}$ The Salvation Army rewarded her upward striving in 1957 not only by encouraging her family's move to Millicent but also by inviting her to attend in London a World Conference of the Salvation Army for Women. To deliver a ten minute speech to several thousand people in Westminster Hall was 'an experience I'll never forget' and the beginning of a lifetime of 'talking' as an active member of the Salvation Army, specialising in the 'Womens' Fellowship'. ${ }^{27}$

Assimilation did not mean that Dulcie and Lindsay turned their backs completely on Raukkan folk nor on their Aboriginal heritage. They gave their children holidays with her Uncle Bruce and Cousin Oky on Yalkuri Station (near Raukkan) and at the Coorong. However, Dulcie does not mention contact with her father other than briefly noting his death. Her husband Lindsay maintained a specific link with the Ngarrindjeri past. At the request of the Australian and the South Australian Museum, Lindsay applied himself to Aboriginal crafts in which he had been instructed by Ngarrindjeri elders in his boyhood. He made occasional use of the Ngarrindjeri language, and he served on a Heritage Committee whose concerns included maintaining an Aboriginal burial ground. Doctoral students in archaeology and anthropology interviewed Dulcie and Lindsay to gather data on Ngarrindjeri culture.

When Dulcie resumes the story, in 'Today's bridges', she thus presents herself confidently as a bearer of Ngarrindjeri heritage, qualified to criticise others' representations of that heritage. Before the Hindmarsh Island controversy, she reports, she and Lindsay had become aware that Lindsay's account of Ngarrindjeri history was not consistent with what some 'younger Aborigines' were saying. The representations to which she objects are not discrete facts of history and folklore. Rather Dulcie is at odds with the whole thrust of historiography and social policy since the early 1970s that treats Aborigines as having a special grievance. 'Much has been said about Aboriginal people being disadvantaged, and dispossessed of their land and heritage since colonisation. I agree that this did happen, during the early settlement and right through to the 1950 s. $^{28}$ She implies that the 1950 s were a turning point, a termination of maltreatment and the start of something better. Having experienced the benefits of assimilation, she is uneasy about the land rights policies and the special programs of Aboriginal support that followed. As she sees it, an alliance formed between certain Whites and certain Blacks to foster a sense of aggrieved racial separatism among Aborigines - 'the notion that this is their land, that white Australians are intruders' ${ }^{29}$ She is amused, she says, 'to hear some of the Aborigines wanting more land, for I have seen first hand many acres of their land not being used'. ${ }^{30}$ She thinks that when the State assists Aborigines on low income - to buy a home, for example - it is 'an act of gross discrimination against those Aboriginal people who are trying to rise above the generalised perception of Aboriginals by helping themselves'. ${ }^{31}$ Why should those who have 'lazed about with 
the hand-out mentality' find it easier to get assistance, she wonders. ${ }^{32}$ In Dulcie's view, a spuriously aggrieved perspective on the past has encouraged some Aborigines and their allies in governments and church organisations to uphold social policies that were unfair to the Aborigines, such as herself, who had thrived by embracing assimilation.

Her experience of ATSIC (Aboriginal and Torres Strait Islander Commission) in the early 1990s deepened her fear that this new orthodoxy was becoming institutionally powerful. 'During ATSIC meetings, some of the councillors who had never been employed by Aboriginal organisations, myself included, were made to feel that they knew nothing about Aboriginal issues. ${ }^{33}$ From her increasingly critical perspective, and not because of any opinion about the proposed Hindmarsh Island bridge (about which she claims disinterest), the Ngarrindjeri assertion that Hindmarsh Island is a sacred women's site struck her as outrageous nonsense, the last straw, a provocation to the Ngarrindjeri 'silent majority' to speak out. ${ }^{34}$ Dulcie narrates her dissidence as a test of her character, a Christ-like ordeal: 'Why am I subjecting myself to all this trauma?'35 To involve herself in public controversy was to suffer for a noble cause. ${ }^{36}$ She denounces several Ngarrindjeri people by name, and she says that she feels betrayed by one of the archaeologists who had interviewed Lindsay and herself. She is appalled that ATSIC and the Aboriginal Legal Rights Movement resourced the 'misrepresentation'. She rejoices in the findings of the 1995 Stevens Royal Commission that the 'women's business' was a fabrication, and she concludes her life story by evoking the giddy pleasure of dining with her champions from the Howard Cabinet.

\section{Doris Kartinyeri}

Doris Kartinyeri, as she tells in Kicking the tin, has long suffered a mental illness known as bipolar affective disorder (or manic depression). She does not tell us how old she was when she received this diagnosis, though she says that her first acute episode of the illness took place in 1984, when she was 39. She appears to have written the book in her early fifties (that is, in the late 1990s). She devotes more than the last third of her book to describing her episodic manias and depressions and the admissions to hospital and treatments that they occasioned, and one of the conceptions of her self that unifies her narrative is that of a sufferer who has battled to control her illness. She is a damaged 'self', in recovery. In one of her final paragraphs she accounts for her sickness by referring to the things that had been done to her earlier in her life by cruel, exploitive and irresponsible authority: 'I believe that my illness resulted from the combination of deception and despair throughout my life. I believe that I am only now coming to terms with all that I endured in the past. ${ }^{37}$ Her illness, or at least her medicated management of it, is thus a source not only of suffering but also of knowledge about what, in her view, caused her illness. To write a book reviewing her life in these terms has helped

\footnotetext{
31. Wilson 1998: 64 .

32. Wilson 1998: 65 .

33. Wilson 1998: 168.

34. Wilson 1998: 150 .

35. Wilson 1998: 153 .

36. Wilson 1998: 173.

37. Kartinyeri 2000: 135 .
} 
her to be 'healed of all my anguish and disillusion'. ${ }^{38}$ 'My healing began when I decided to write an autobiography' ${ }^{39}$

What happened to Doris?

Doris Kartinyeri was an inmate of Colebrook, an institution for Aboriginal children started in 1924 by the United Aborigines' Mission. In the late 1990s, the third site of Colebrook Home, the Training Centre at Eden Hills (opened in 1943, closed in 1972) became a place of collective remembrance for many of South Australia's Aboriginal families, who attended ceremonies there that unveiled statues and plaques. Doris's contribution to the lore of Colebrook begins by her writing that she lived the first 14 years of her life there (at Eden Hills), without ever being told that her mother had died shortly after her birth and that she had been removed from her family even though they had been willing to look after her. The family story, obtained recently from her sister Doreen, is that their father mistakenly signed Doris into Colebrook; he thought he was signing a form to receive Child Endowment payments, and he was unable to persuade the South Australian government to let him have her back.

Nonetheless, there was affection at Colebrook - among the children and between the children and some of the staff. 'We were happy in our own way, laughing, crying, and just being an extended family with a lot of love ... I felt secure with my many brothers and sisters. ${ }^{40}$ For the first seven of Doris's 14 Colebrook years, she was under the care of Sisters Hyde and Rutter - 'two wonderful women' whose presence gave Doris 'a sense of security, belonging and love that I was unable to receive from my true family' ${ }^{41}$ The recalled incidents of her childhood at Colebrook are at first happy, unremarkable stories of play; the children enjoyed adequate food from the kitchen and they gathered 'bush tucker' from the land surrounding the Training Centre. 'I am amazed at our natural instinct for bush food. We had our heritage taken from us but we still had the natural instinct for finding the right foods. ${ }^{42}$ As Doris recalls her experience, Colebrook was an emotionally complete world. From time to time, Doris's father, brothers and sisters visited her, but Doris recalls these as uneasy occasions. Her father did not mention her mother's death, and Doris recalls finding it difficult to address him as 'Dad'; and she also remembers telling her sister that, really, her only brothers and sisters were the other Colebrook children. ${ }^{43}$

Colebrook children lost their security after the departure of Hyde and Rutter in 1952 - Doris calls this chapter 'the beginning of grief' - for the succeeding staff were more strict and more religious. Wetting the bed was, to them, an offence to be punished. Doris believes that the masters and mistresses of the new regime 'have a lot to answer for. The strictness affected many of our brothers and sisters. This is one of the reasons I believe a majority of our sisters and brothers went to either gaol or mental institutions. Others suffered with alcoholism. All in the name of Religion! ${ }^{\prime 44}$ This strict

\footnotetext{
38. Kartinyeri 2000: 112.

39. Kartinyeri 2000: 1 .

40. Kartinyeri 2000: 14.

41. Kartinyeri 2000: 16-17.

42. Kartinyeri 2000: 26.

43. Kartinyeri 2000: 47.

44. Kartinyeri 2000: 43.
} 
regime was sometimes the cover for sexual predation by Colebrook staff. This is how she introduces a series of disturbing encounters with a woman staff member: 'As an individual child with no family there to protect me, and being black, naive and vulnerable, I was easy prey for the sexual predators. Colebrook seemed to be a haven for sexual deviants. It was a terrible place to live for a lot of the children. ${ }^{45}$

After leaving Colebrook - not her decision - at 14, Doris was assigned to a series of white families around Adelaide while completing her education. She later acknowledges that when she first left Colebrook 'I hadn't realised that there was a large family circle to meet. 46 The imposed substitute for her family circle proved to be utterly inadequate in that one of her assigned carers was sexually exploitive. Doris writes that as an Aboriginal girl under the 'protection' of Church and State, she lacked effective protection from the greatest threat of all, the sexual pervert disguised as a man of God. Without the security of Colebrook, the importance of being part of a family began to be borne in on her. 'My family was out there but I had no indication where they were. Were they searching for me? I needed to find out who my family was because I wanted them so desperately. ${ }^{47}$ Yet she 'did not know how to approach them as a member of a family should', and her first employer, a Methodist nursing home, advised her not to contact her family. ${ }^{48}$ Doris implies that she was influenced by such advice. Not yet 16 years old, under the pressure of this emotional isolation and sexual vulnerability, she lost her 'dignity, self respect and, most importantly, my identity and sanity'. ${ }^{49}$ When her sister Connie visited, Doris 'was just numb for the words to tell' ${ }^{50}$ She recalls herself as then lacking a self: ' 1 just did not have any goals in life, nor dreams, nor direction. I was just drifting. ${ }^{51}$

Doris's account of her two relationships with men - the second a marriage - and of the birth of three children is startlingly brief. Doris continued to search for 'her people' and for the security that men could not give her. ${ }^{52}$ Adelaide's Carrington Hotel was an informal meeting place for the region's Aboriginal people, though the combination of alcohol, Aborigines and police could make trouble. By frequenting the Carrington, Doris was able to meet 'a large number of my aunts uncles and cousins' which 'gave me a sense of belonging'. ${ }^{53}$ One of them persuaded her to move to Raukkan, the place of her birth and, as she was learning, part of the homeland of her people, the Ngarrindjeri. She recalls that it was difficult to find acceptance among the Ngarrindjeri at Raukkan, and so she moved to the nearby town of Murray Bridge. ${ }^{54}$ As her contact with the Ngarrindjeri continued, she found 'aunties, uncles, cousins, all over the place. It was very difficult to know them all. ${ }^{55}$ She found the language difficult.

45. Kartinyeri 2000: 54.

46. Kartinyeri 2000: 73.

47. Kartinyeri 2000: 62.

48. Kartinyeri 2000: 65.

49. Kartinyeri 2000: 62-3.

50. Kartinyeri 2000: 63.

51. Kartinyeri 2000: 66.

52. Kartinyeri 2000: 71.

53. Kartinyeri 2000: 73.

54. Kartinyeri 2000: 76.

55. Kartinyeri 2000: 78. 
It is a striking feature of Doris's account of her early adulthood, back in Ngarrindjeri country, up until the commencement of her mental illness, that she recalls rejection not by whites but by the Aborigines whom she sought as her kin. She found them negative and judgmental: 'the past always seemed to be brought up and they always had the habit of putting people down'. 56 Treated as an outsider, she turned to the consolations of alcohol.

Because this is the moment in her life-story when she begins to narrate the onset of mental illness, the reader is sensitive to her recollection that the Ngarrindjeri community was, at first, no haven. On the contrary, among the experiences that made her miserable (and that may have precipitated her illness) we must include not only the sudden withdrawal of Colebrook's nurturing atmosphere, but also the emotional austerity of Colebrook in its stricter moments, and the humiliating sexual impositions by authority figures. We can also get from Doris the story that she was left stranded by the unwillingness or the incapacity of her Ngarrindjeri family to re-absorb an estranged kinswoman. To point this out is not to criticise her family for want of compassion, for Doris mentions a number of approaches by sisters Connie and Doreen; and we should remember that to produce ambivalence (at the very least) about one's Aboriginal kin was one of the objectives of the training to which Doris herself had been subjected.

Doris gives few details about her interactions with her relatives in her twenties and thirties. Indeed, there is a contradiction, suggestive of emotional difficulty - in her brief mentions of her father. Doris writes that she eventually came to understand that he was 'an angry man. I can understand why he was angry.' However, 'as I matured and got to know my natural family, we became very close and a strong bond developed' ${ }^{57}$ However, 34 pages later, recalling the moment when she heard of her father's death, she writes: 'I had no emotions and couldn't cry. The emptiness I felt left me hollow. I really never got to know my father. 58

At the point in the story when Doris becomes mentally ill, then, she has not found a place within her kin network. However, by the end of the book, 60 pages later, she can report that she has found such a place, and not onily because she is now a grandmother. 'It's bloody good that now I can sit with my family and friends and my brothers and sisters around the table, laughing and joking about all the bizarre incidents in my life. ${ }^{59}$ What made the difference? Two themes run through those 60 pages, and both are about (what I wish to call) 'public reassignments' of Doris Kartinyeri.

She is given the status of a mentally ill person; she reports her daughter Jennadene saying to her that 'insanity is the safest place to be mum' ${ }^{60}$ And, as the Stolen Generations and Hindmarsh Island issues emerge, she acquires the status of a marginalised, maltreated but articulate Aboriginal person. Both reassignments contribute to the emergence of the author who, at the end of her autobiography, celebrates her belonging to a network of Ngarrindjeri kin.

\footnotetext{
56. Kartinyeri 2000: 78.

57. Kartinyeri 2000: 43, emphasis added.

58. Kartinyeri 2000: 77, emphasis added.

59. Kartinyeri 2000: 136.

60. Kartinyeri 2000: 101.
} 
In narrating the emergence of this self who can write confidently about her own suffering, Doris tells several stories about her delusional and manic states and about being treated for them. While paying a warm tribute to her psychiatrist, Dr Kenny, she says that she received no support from Aboriginal Health, explaining this neglect as the result of 'ignorance and that people are wary of mental illness'. ${ }^{61}$ There were other sources of support, such as the Bellara nursing home, where Doris worked for four years. She tells of her colleagues' tactful handling of one of her manic episodes in that workplace. Rejoicing in her newfound identity as a writer, she thanks her TAFE (College of Technical and Further Education) teachers, Don and Una Strempel, and her tutor Zora, for improving her literacy. Interspersed among these acknowledgments of support and care are fond mentions of her daughter Jennadene and her daughter-inlaw Jennifer, and her clear delight in being a grandmother. Reminiscences with other former residents about Colebrook's uglier moments become episodes of healing, in Doris's telling, but they also fuel her anger at the government and the churches, an anger that rises as the book draws to a close. Colebrook, at this point in the book, is evoked with terrible stories about sexual abuse of the boy residents, with long-term damage to the men in her generation.

The movement among the Stolen Generations to have their experiences recognised gave Doris a public platform for such memories. In conference presentations about her life at Colebrook she helped to exemplify the Stolen Generations. Colebrook itself became the site for a series of ambivalent commemorations that she attended with enthusiasm. For the very reason that she was credible as a speaker on Colebrook, however, she had to be marginal to the struggle to preserve women's sacred sites on Hindmarsh Island. Yet she celebrates her solidarity with other Ngarrindjeri who promoted the sacredness of that disputed place.

I wanted to support the Ngarrindjeri women but I couldn't because I didn't know how to. Thanks to the Government, I had my heritage taken away from me when they removed me from my family. I didn't receive the history of my people and had awfully little knowledge about my culture and my heritage. Women's business was never passed down to me but I believed this group of women was fighting for what they believed in. I became a victim full of anger and hopelessness. ${ }^{62}$

The combined effect of the Stolen Generations and Hindmarsh Island campaigns was a public framework of sympathetic understanding in which Doris's disinheritance could be represented as an attribute of her contemporary Aboriginality. The available Aboriginal identities, in the moment of her book's writing and reception, included the damaged identity of a Ngarrindjeri person who admits that she does not know her Law. Her mental illness is similarly transformed into something positive; it is narrated as her suffering Aboriginality. 'The battles and struggles of living in two worlds that I endured throughout my life have proven my aboriginality. ${ }^{63}$ By giving rise to the figure of the abused and suffering Aboriginal subject, the Hindmarsh dispute, the Stolen Generations inquiry and the reconciliation movement have combined to produce

61. Kartinyeri 2000: 100.

62. Kartinyeri 2000: 125.

63. Kartinyeri 2000: 135. 
a public culture in which her sick and damaged self can be presented by Doris as the exemplary product of a personal and a national history.

\section{Veronica Brodie}

Veronica Brodie's book was not conceived as a response to the way that Ngarrindjeri identity was represented in the Hindmarsh Island struggles. Mary-Anne Gale's introduction tells us that the dispute erupted when the book was being edited in a three-way collaboration between Mary-Anne herself, Brodie and the publisher Wakefield Press. And the book opens with Veronica explaining the contemporary significance of her Kaurna, rather than her Ngarrindjeri, heritage (she is descended of both). However, the editing process was sufficiently prolonged to allow her to write two chapters (a little more than ten per cent of the book) on the Hindmarsh matters; they are placed late in the book, so that her life narrative leads up to her involvement in the Hindmarsh affair.

Veronica Rankine was born at Raukkan in 1941. Her recurring presentation of herself is as a person who is able to recommit herself to self-denial. Like Dulcie Wilson, Veronica recalls Raukkan adults' discipline as a beneficial formation of her character, disposing her to listen respectfully to adult authority and to be careful how she posed questions. 'Learning that part of the culture was good, and I appreciate that today that discipline I got then.' ${ }^{64}$ Nowadays, she reflects, discipline as a way of caring for the young has lapsed. ${ }^{65}$ Evoking the poverty of the Raukkan residents, she recalls the mission's austerity as enabling her to do without; it freed her of the desire for material things that causes other people 'terrible anguish'. 'I'm more interested in my heritage and spirituality and genealogy ... the cultural side of life' ${ }^{66}$ Later in the book she returns to the theme of 'greed' as the nemesis of Aboriginal culture. ${ }^{67}$ Here it is relevant to mention that Veronica is diabetic, so food itself is a test of fortitude. This colours her account of a formative overseas trip. Her visit to India in 1988 'forced me to evaluate my own life and my own source of food - it made me look at my whole self. After that trip I said, "If I don't have a loaf of bread, or if I miss a meal, I won't grizzle and I won't gripe, because those humble people in India have taught me that." They taught me never to be selfish.' 68

A theme of Veronica's story is her growing understanding of the ways that her life was shaped by authorities - both the adults in her family and by the state. As an adolescent, Veronica was placed under the caring discipline of sisters Hyde and Rutter, after they had left Colebrook to take charge of Tanderra, a United Aborigines' Mission hostel for Aboriginal high school students. She came to accept the good intentions behind the matrons' close supervision. She and the other girls were being taught how to live in the city. 'They knew what the city had to offer Aboriginal girls, and believe me, it wasn't a lot! ${ }^{69}$ Before living at Tanderra Veronica had been sent to live in Adelaide with relatives, from time to time, and she later realised that this was to spare her the

\footnotetext{
64. Brodie 2002: 43 .

65. Brodie 2002: 52.

66. Brodie 2002: 25.

67. Brodie 2002: 148.

68. Brodie 2002; 124.

69. Brodie 2002: 60 .
} 
violent periods in her parents' relationship. There were other ways that the adults at Raukkan determined her life, but I will come back to them later.

While in Adelaide, she began to understand how law and bureaucratic regulation recognised certain city-dwelling Aboriginal relatives as different, as 'exempt' from the laws that discriminated against Aboriginal people. At one point, her visiting father introduced her to his exempted sister Olga, with whom he had not associated since she left Raukkan at the age of 13. It was at this reunion of brother and sister that Olga's husband learned for the first time that his wife had been born into an Aboriginal family. As an Aboriginal woman 'passing' as 'white', Olga had not mentioned this to her husband. Official regulation of the boundary between legally-defined Aborigines and exempt or 'passing' Aborigines was sometimes reinforced by such self-regulation of the two classes of people. Veronica's exposure to the Protection Board as an adolescent and as an adult allowed her to sympathise with people's investment in these differences of status: 'you can understand why older people who could pass off as white did take the opportunity'. ${ }^{70}$ This was the stratified and regulated world of city and rural South Australia in the 1950s, the world that the Tanderra matrons were teaching Veronica and her classmates how to deal with. As Veronica gratefully recalls: 'they showed us how to fight back without anger, because they knew what the Protection Board was like'. ${ }^{71}$

Veronica was not given the option of going beyond the Intermediate Certificate (Year Nine) at Unley Girls Technical High School 'because if you got too educated you might cotton on to what they were up to', as Veronica explains. ${ }^{72}$ Possibly, this is her retrospective comment on the system; she also states her gratitude to the Tanderra matrons, Rutter and Hyde: 'They were a real caring sort of couple' who supported her decision to train as a nurse. ${ }^{73}$

In the middle sections of her book, Veronica recounts a series of clashes with the officers of the Protection Board, with the Board trying to tell her for whom she should work, when she left nursing, and where she should live. As she recalls, 'exemption' could be a threat as well as a rewarding recognition of an Aboriginal person's efforts to uplift herself. If the Protection Board punished her recalcitrance by exempting her, 'I would be excluded from my home for the rest of my life' - that is, she would be forbidden to associate with Aboriginal reserve residents who had not been exempted. ${ }^{74}$ Indeed, the Board demonstrated that it could inflict this punishment simply by refusing her permission to visit Raukkan. She endured three such refusals before she complained to a Member of Parliament, who spoke to the Protection Board officials on her behalf. Veronica was not legally exempt until she married an exempt Aborigine, Jim Brodie. 'Jim never spoke much about his family. They were funny. They knew they were Aboriginals, but to admit it was another thing. ${ }^{75} \mathrm{Jim}$ and Veronica did not allow

70. Brodie 2002: 88 .

71. Brodie 2002: 61 .

72. Brodie 2002: 63 .

73. Brodie 2002: 69 .

74. Brodie 2002: 74. South Australia's Aborigines Act 1934 had introduced the possibility of 'exemption'. In 1953 the Police Offences Act included a Section making it an offence for nonAboriginal people habitually to 'consort' with Aborigines 'without reasonable excuse'. An exempted person would thus be at risk of prosecution if he/she associated with an Aboriginal friend or relative who was not also exempted. This Section was repealed in 1958. 
their status to prevent their receiving non-exempt Ngarrinjeri relatives into their home. Veronica concurs with Dulcie Wilson in recalling the late 1950s and early 1960s as a time when Raukkan residents were becoming fed up with the mission's limited opportunities and were seeking other places to live, including Adelaide where exempt relatives resided. ${ }^{76}$

Veronica's experience of exemption was short-lived, for legislative reform in the mid 1960s was dismantling the framework of Protection Board control and thus dissolving the statutory distinction between Aborigines and others. She writes that she experienced this moment of Aboriginal emancipation as the government giving her permission to be Aboriginal once more. She reflects that had she lived a long time as 'exempt' she might have lost her sense of being Aboriginal. ${ }^{77}$ One of her ways to hang on to her sense of being Aboriginal was to refuse one of the fruits of policy reform, the right to vote. ${ }^{78}$

Veronica's narrative of the late 1960s to late 1970s (her late twenties and thirties) is very brief; she mentions a few jobs, the departure of her husband, her alcohol problem and her recovery from it. This sets the scene for what she calls 'my spiritual awakening' in 1979 (when she was 38). One source of this awakening was her older sister, Leila Rankine. Leila had lived much longer at Raukkan than Veronica before moving to Adelaide and becoming a key figure in Adelaide University's Centre for Aboriginal Studies in Music. When Veronica's rehabilitation under the regimen of Alcoholics Anonymous climaxed in a 'spiritual awakening' - an overnight event confirmed to her by her psychotherapist - Leila became a close supporter of her continuing recovery. Having told us that, Veronica does not make Leila a large character in the next few chapters - dealing with her work in alcoholics' rehabilitation institutions, with her visit to India in 1988 and with her work for the Aboriginal Housing Board - until Leila's death in January 1993. It is Leila's death that brings Veronica's narrative to the 'Hindmarsh Island Bridge Affair'.

Just before dying of a long illness, Leila told Veronica the secret women's law of Kumarangk. Veronica explains to the reader why she had not previously been told. Her mother had judged Leila to be the more responsible daughter, closer to the culture. As Veronica explains, making sense of it now: 'Mum knew I was drinking and carrying on

75. Brodie 2002: 88 .

76. Brodie 2002: 97.

77. Brodie 2002: 100

78. The Aboriginal Affairs Act 1962 repealed the Aborigines Act 1934 while continuing some of its 'protective' powers. It was no longer possible to force an Aboriginal person to live on a reserve. The term 'half-castes' was no longer used, but those not of 'full blood' were still considered to be of 'Aboriginal blood' if they were not specifically exempted. Those exempted had their names removed from the Register of Aborigines. If you were removed from the Register then the Aboriginal Affairs Act did not apply to you. A 1962

Commonwealth law made it possible for all Aborigines to vote in Commonwealth elections whether or not their own State enfranchised them. In 1966 South Australia's Prohibition of Discrimination Act made it illegal to refuse to serve, accommodate and admit to any place 'by reason of that person's race or country of origin, or the colour of his skin'. In 1967 Aborigines obtained by legislative amendment the same rights to drink as others in South Australia (and Executive action had effected this in 1965). In 1968 South Australia abolished its Register of Aborigines. 
like I was, and she thought I certainly wasn't a good person to tell any of the sacred cultural stuff to. ${ }^{.79}$ The reader could connect this explanation to a passage 90 pages earlier in which she recalled the fears of Raukkan's senior people when she was a child. They had given only minimal answers to children's questions about Ngarrindjeri language and culture because they knew that 'whiteman would come in one day and take the language, and learn more about the ways, and so nothing would be safe any more. ${ }^{\prime 80}$ As Veronica tells, she has inferred (back then or more recently? It is not possible to know) that in the late 1940s and early 1950s the older Ngarrindjeri did not trust the younger ones to keep Ngarrindjeri knowledge safe from 'whiteman' appropriation. Now, in the early 1990s, her sister was revealing that she had been entrusted with something important and was prepared, on her deathbed, to entrust that knowledge to Veronica.

She saw that I had been so many years off the drink, and I was capable of being told the women's business. So she told me, and I was quite amazed - I was quite shocked. It really opened my eyes. I didn't know any culture like that existed for our Ngarrindjeri women, but it does! $!^{81}$

Veronica then immediately considers how that knowledge affects her own responsibilities.

If only our younger Ngarrindjeri women could learn of it, it might help them - it might do something for them. It won't, however, unless they're prepared to give up some of their present life, and the way they're living life today. I believe you've got to combine Aboriginal culture with what you're doing - you've got to have strength to draw on that Aboriginal culture. But while you're living the wild way and doing all these foolish things, you're certainly not going to be able to give to your culture. So you have to make a decision. ${ }^{82}$

After Leila's death, Veronica explains to Leila's children that she will not tell them what their mother told her because their lifestyle showed them to be 'blabbermouth'. They would be told, when older people judged them worthy to receive. ${ }^{83}$

This is not the first passage in which Veronica has reflected on the moral gap between herself and the young. Earlier in the book, her account of the Protection Board includes the following ambivalent reflection on the way the Board's invigilation had been a harsh test.

Our young ones today - we hear them say how hard life is for them. But I often wonder, if younger people had had our lives to live, what would they do? I could not imagine it. I could never, ever imagine them living the kind of life that we did under the Protection Board system. They'd never survive, because they wouldn't know how to. It was very difficult, you know. It's no wonder that it sent some of us to the drink! $!^{84}$

\footnotetext{
79. Brodie 2002: 145.

80. Brodie 2002: 53.

81. Brodie 2002: 146 .

82. Brodie 2002: 146 .

83. Brodie 2002: 146 .

84. Brodie 2002: 112 .
} 
One good legacy of the trying and insulting Hindmarsh Island Bridge Affair, for Veronica, is that her own daughters 'have come out now and are badgering me and saying, "Mum, we want to know more"'. ${ }^{85}$ She now feels herself to be part of a cultural system that links knowledge with virtue.

Because that's how things are handed down. Not, as some people might think, automatically from generation to generation. It's handed down in such a way that a mother or an elder judges whether a particular person is wise enough and ready for responsibility. 86

We could say that one of the benefits of the bruising Hindmarsh ordeal is that it renewed and amplified Veronica's moral authority over her children.

\section{Varieties of Ngarrindjeri virtue}

It was the practice of governments to constitute Indigenous Australians as certain categories of person: by age, by sex, by descent, by colour, and by intensity of government supervision. Reading these three Ngarrindjeri autobiographies gives us the opportunity to understand how these distinctions could become powerful in people's lives. It is part of their effect that they produced more than one way to be situated in relation to Ngarrindjeri heritage. Doris Kartinyeri, by her own account, was effectively blocked from that heritage; however, her dispossession validates her, now, as exemplifying a certain Ngarrindjeri experience. Veronica Brodie and Dulcie Wilson narrate themselves as receivers of Ngarrindjerri heritage, though in different ways. Through her sister, and to her own admitted surprise, Veronica had access to Law that her mother's generation had decided not to pass on to her. Evidently, no-one passed such knowledge on to Dulcie, but she was sufficiently confident of the completeness of her understanding of Ngarrindjeri law that she did not find it credible that members of her own generation could know things withheld from her. ${ }^{87}$

The autobiographies of Veronica and Dulcie show them to be alike in their sense of being women who have been tested. Dulcie evokes her own goodness in terms of her good works, her prayer and her courageous dissent from powerful, public accounts of Aboriginality that she finds repugnant. She stands up bravely for the truth of her understanding of her Ngarrindjeri heritage. Veronica presents herself as a woman who clung to Aboriginality in the face of the temptations of 'passing', who shook off the grip of alcoholism and who distances herself from the pleasures of a materially self-indulgent, 'greedy' society - influences to which many other Aborigines succumb. Her success against these distractions and corruptions is rewarded, to her surprise and pleasure, by her sister's recognition of her as worthy to carry a knowledge the possession of which is the mark of a distinctly Aboriginal virtue. She now is a judge of others' fitness to receive that heritage.

85. Brodie 2002: 183.

86. Brodie 2002: 183 .

87. One difference between the 1995 Stevens Royal Commission and the 2001 von Doussa review of its findings is that when Stevens questioned the dissident women, their proclamation that they knew nothing of the 'secret women's law' was taken as strengthening the argument that there was no such thing; in the proceedings under von Doussa, the dissident women's 'lack of knowledge of secret women's business proved little or nothing' (Simon 2003: 446). 
Are the dissident Ngarrindjeri women of Veronica's generation like those youngsters raised by Veronica and Leila - wayward, but redeemable? On this question Veronica is clearly uncomfortable and ambivalent. On the one hand, she would like to sit down with women such as Dulcie, hear them out, and explain to them that they have allowed themselves to be manipulated by greedy whites. ${ }^{88}$ On the other hand, 'They should be ashamed to call themselves Ngarrindjeri, they are from Raukkan. So it's no wonder they weren't told any secrets about it. The old women were very careful about who they told their secrets to. ${ }^{89}$ Her closing words are conciliatory. 'I must say that I still love the dissident women, as I love all Ngarrindjeri women, despite what happened. ${ }^{90}$

Different as they may be in their ways of being Ngarrindjeri, these three women can all partake of that wider autobiographical idea, the suffering Aborigine who survives to narrate the story of their suffering. And each of them can present her suffering in reference to some public account of what it is to be Aboriginal. Doris finds her Aboriginal voice by making her story an exemplar of the Stolen Generations. She can plausibly trace her mental illness to the version of that story which emphasises its elements of child abuse, even while acknowledging that there was much in the Colebrook experience that was warm and good. Veronica, the recovering alcoholic, plausibly accounts for her abuse of alcohol by reminding us about what was shaming in the government's policy of selective exemption. As someone who throve on assimilation, Dulcie's suffering, and her triumph over it, came much later. She was not a Stolen Child; she flourished as an assimilating Aborigine. It is the post-assimilationist public account of Aboriginality that she finds oppressive: the idea that her people had so much taken from them and are now owed so much. As she sees things, people who have not uplifted themselves are now rewarded with handouts. Perhaps the most repugnant feature of contemporary public Aboriginality for Dulcie - though this is not explicit in her book - is that there are now other traditions of virtue than those which honour her as a steadfast soldier in Christ's army. When the keepers of the secrets of Kumarangk explain why they know something that the dissident women such as Dulcie don't know, they invoke not only an inheritance of knowledge, but also a continuing practice of judgment about who is virtuous enough to bear the cross of being Aboriginal in contemporary Australia.

So, who has the authority to speak for the Ngarrindjeri? No one person or entity, it seems. 'Our Ngarrindjeri nation was a proud nation once', writes Veronica. ${ }^{91}$ Is univocal history a condition of the recovery of that 'national' pride? When Aboriginal people write history by writing autobiographies, are they not likely to undermine the presumption of a common Ngarrindjeri heritage, and therefore perhaps undermine the 'Ngarrindjeri nation'? An Indigenous historiography that is largely autobiographical is a relatively poor basis for a sense of 'nation' as common heritage; the generic emphasis on 'individuality' is the antithesis of the homogenising tendency of a 'national' historiography that makes 'culture' the test of nationhood.

88. Brodie 2002: 148.

89. Brodie 2002: 157-8.

90. Brodie 2002: 188.

91. Brodie 2002: 148. 
Collectivities such as 'Ngarrindjeri' are imaginative constructs, and so are all nations. However, some of these imaginative constructs deploy material processes that effect boundaries and processes of representation. Within Australia's processes of representation, we now have a space called 'heritage'. Those who use this space to proclaim a 'heritage' may find themselves under inspection in their representation of it. By articulating it, they have ensured that it is no longer simply their own to reproduce. My intention in discussing these three Ngarrindjeri autobiographies is to understand the biographical roots of publicly competing representations of the Ngarrindjeri heritage. We can see, I hope, why Justice Matthews came to the conclusion that both sides were sincere in their competing claims about that heritage; they were true to their lived experience of being Ngarrindjeri. However, the three books also allow us to empathise with the shock that each author experienced in finding that heritage made public is contestable. When 'Ngarrindjeri' heritage became open to diverse invocations, the state intervened using its powers over the representational space 'heritage'. It is a feature of the contemporary Indigenous Australian scene that when rival protagonists of the Indigenous heritage seek authoritative closure, they may turn to external adjudicators. Heritage made public is not only theirs to manage. That the Indigenous polity is nested within the over-arching non-Indigenous political and legal system is not necessarily a disabling feature of Indigenous politics: the colonial state solicits Aboriginality and stimulates rivalries among those bearing that heritage, while at the same time providing the means of resolution between those contending 'Aboriginalities'. That the result leaves some people unhappy and dissatisfied should surprise no-one who has a realistic view of empowerment. The benefit of this sometimes bruising process, however, is its stimulus to Aboriginal people's history-making, as my study attempts to show. The Hindmarsh Island controversy gave each author reason (perhaps additional reason) to become autobiographical.

\section{References}

Berndt, R, C Berndt and J Stanton 1993, A world that was: the Yaralde of the Murray River and the lakes, University of British Colombia Press, Vancouver.

Brewster, Anne 1996, Aboriginal women's autobiography, Sydney University Press, Sydney.

-2002, 'Aboriginal life writing and globalisation: Doris Pilkington's Follow the rabbitproof fence', Australian Humanities Review 25, March-May, http://

www.lib.latrobe.edu.au/AHR/archive/issue-March-2002/brewster.html

Brodie, V 2002, My side of the bridge, Wakefield Press, Adelaide.

Brumble, David III 1988, American Indian autobiography, University of California Press, Berkeley 1988.

Cowlishaw, G 2006, 'On "getting it wrong": collateral damage in the history wars'، Australian Historical Studies 127: 181-202.

Dalziell, R 1999, Shameful autobiographiess، Melbourne University Press, Carlton.

Grant, S 2002, The tears of strangers: a memoir, HarperCollins, Sydney.

Green, J and W Rubuntja 2002, The town grew up dancing, Jukurrpa Books, Alice Springs.

Gusdorf, G 1980, 'Conditions and limits of autobiography' in J Olney (ed), Autobiography: essays theoretical and critical, Princeton University Press, Princeton: $28-48$. 
Hooton, J 1990, Stories of herself when young, Oxford University Press, Melbourne.

Kartinyeri, D 2000, Kicking the tin, Spinifex Press, North Melbourne.

Matthews, Gordon 1996, An Australian son, William Heinemann, Port Melbourne.

Krupat, Arnold 1985, For those who come after, University of California Press, Berkeley.

- 1989, The voice in the margin: Native American literature and the canon, University of California Press, Berkeley.

- 1992, 'Native American autobiography and the synecdochic self', in A Krupat Ethnocriticism: ethnography, history, literature, University of California Press, Berkeley: 173-200.

— 1994, Native American autobiography: an anthology, University of Wisconsin Press, Madison.

McCooey, D 1996, Artful histories, Cambridge University Press, Oakleigh, Victoria. Morgan, S1987, My place, Fremantle Arts Centre Press, Fremantle.

Murray, D 1991, Forked tongues: speech, writing and representation in North American Indian texts, Indiana University Press, Bloomington and Indianapolis.

O'Brien, LW 1973, Plains Indian autobiographies, Boise State College Western Writers Series, No 10.

Povinelli, E 2006, 'Finding Bwudjut: common land, private profit, divergent objects', in T Lea, E Kowal and G Cowlishaw (eds), Moving anthropology: critical indigenous studies, Charles Darwin University Press, Darwin: 147-166.

Rowse, Tim 2004, 'Indigenous autobiography in Australia and the United States', Australian Humanities Review August-October, http://www.lib.latrobe.edu.au/ AHR/archive/Issue-August-2004/rowse.html.

— 1993a, 'The Aboriginal subject in autobiography: Ruby Langford's "Don't take your love to town"', Australian Literary Studies 16(1): 14-29.

- 1993b, After Mabo, Melbourne University Press, Carlton South.

Simon, M 2003, The meeting of the waters: the Hindmarsh Island Affair, Hodder, Sydney.

Wang, HD 1992, Sending my heart back across the years, Oxford University Press, New York and Oxford.

Watson, J and S Smith 1992, 'Introduction: de/colonisation and the politics of discourse in women's autobiographical practices', in S Smith and J Watson (eds), De/ colonizing the subject: the politics of gender in women's autobiography, University of Minnesota Press, Minneapolis: xiii-xxxi.

Whitlock, G 2000, The intimate empire: reading women's autobiography, Cassell, New York.

Weintraub, K 1975, 'Autobiography and historical consciousness', Critical Inquiry 1(4) June: $821-48$.

Wilson, D 1998, The cost of crossing bridges, Small Poppies Publishing, Mitcham, Victoria. 